Supporting Information for

\title{
Novel multistage electrochemical flow-through mode (EFTM) with porous electrodes for reclaimed wastewater treatment in pipes
}

\author{
Cong Zhang ${ }^{1}$, Xin Zhao ${ }^{1 *}$, Can Wang ${ }^{1 *}$, Shuang Pan ${ }^{1}$ \\ ${ }^{1}$ School of Environmental Science and Engineering, Tianjin University, Tianjin, 300350, China \\ * Corresponding author: X. Zhao, C. Wang
}

Tel: (86-22) 8535-6231

Fax: (86-22) 8535-6231

E-mail addresses: xinzhao@tju.edu.cn; wangcan@tju.edu.cn

Text:

S1-S5

Figure:

S1-S10

Table:

S1-S7

Page:

S1-S23 


\section{List of Supporting Information:}

Text S1. Materials

Text S2. The Preparation of Porous Ti-ENTA $/ \mathrm{SnO}_{2}-\mathrm{Sb}$ anode

Text S3. Analytical Methods

Text S4. The Variation of Reclaimed Wastewater Quality Parameters

Text S5. The Calculation of Electrode Numbers for the Practical Flow Velocity

Figure S1. The illustrative diagram of three-stage EFTM

Figure S2. The schematic diagram of novel anodes preparation process

Figure S3. The SEM images of (a) $\mathrm{TiO}_{2}$ nanotube layer and (b) porous $\mathrm{Ti}-\mathrm{ENTA} / \mathrm{SnO}_{2}-\mathrm{Sb}$ electrode (nominal pore size: $50 \mu \mathrm{m}$ ); The (c) SEM picture, (d) XRD spectra and (e) EDS of porous $\mathrm{Ti}-\mathrm{ENTA} / \mathrm{SnO}_{2}-\mathrm{Sb}$ electrode

Figure S4. (a) LSV curves of different electrodes; (b) The comparison of heavy metal leaching concentration for different electrodes

Figure S5. Variation of pressure drop for different modes with the flow velocity

Figure S6. Comparison of the COD and TOC removal efficiency by using the three-stage EFTM Figure S7. The long-term performance of the three-stage EFTM during treatment process

Figure S8. Effect of different stage numbers on (a) COD removal efficiency and (b) pseudo firstorder kinetic fitting by single-stage EFTM and three-stage EFTM. The inserted plots in (a) and (b) are the $\mathrm{EE} / \mathrm{O}$ and pseudo first-order rate constants at different current density, respectively

Figure S9. Effect of stage numbers on (a) bacterial inactivation and (b) the concentration of free chlorine and dissolved oxygen by using the three-stage EFTM

Figure S10. Effects of flow velocity on pseudo first-order kinetic fitting by rate constants $(k)$

Table S1. The water quality of the reclaimed wastewater sample

Table S2. The pressure drop curve for different modes

Table S3. The element content percentage of porous Ti-ENTA/ $/ \mathrm{SnO}_{2}-\mathrm{Sb}$ electrode

Table S4. The comparison of heavy metal leaching concentration

Table S5. The variation of water quality parameters for three-stage EFTM

Table S6. The property comparison of different types of technology in the oxidation of reclaimed wastewater

Table S7. Parameters that used for practical flow velocity simulation 


\section{Text S1. Materials}

Pure titanium foil $(0.25 \mathrm{~mm}, 99.7 \%)$ was purchased from Sigma-Aldrich (China). Perchloric acid $\left(\mathrm{HClO}_{4}\right)$ and tin tetrachloride $\left(\mathrm{SnCl}_{4} \cdot 5 \mathrm{H}_{2} \mathrm{O}\right)$ were purchased from Aladdin Reagent (China). hydrogen peroxide $\left(\mathrm{H}_{2} \mathrm{O}_{2}\right)$, hydrofluoric acid (HF), ammonium fluoride $\left(\mathrm{NH}_{4} \mathrm{~F}\right)$, antimony chloride $\left(\mathrm{SbCl}_{3}\right)$, glycerin and ethanol were purchased from Kmart Reagent Co., Tianjin, China. Acetone, hydrochloric acid $(\mathrm{HCl})$ and yeast extract were purchased from Yuanli Reagent Co., Tianjin, China. Ethylene glycol (EG) and phosphoric acid $\left(\mathrm{H}_{3} \mathrm{PO}_{4}\right)$ were obtained from Kemiou Chemical Reagent Co., Tianjin, China. Citric acid was purchased from Guangfu Reagent Co., Tianjin, China. Tryptone was purchased from Sustyailai Biotechnology Co., Ltd.(China). Chinese Academy of Sciences. Strains of Escherichia coli (GMCC 1.3373) were purchased from the Institute of Microbiology, Chinese Academy of Sciences. 


\section{Text S2. The Preparation of Porous Ti-ENTA/SnO ${ }_{2}-\mathrm{Sb}$ anode}

The porous titanium substrate $(\varnothing 50 \mathrm{~mm})$ with the diameter of $50 \mathrm{~mm}$ and a thickness of 3 mm was polished using 2000 grit abrasive paper to obtain a flat surface and degreased in $\mathrm{H}_{2} \mathrm{O} / \mathrm{H}_{2} \mathrm{O}_{2}$ solution (volume ratio $=5: 1$ ) at $80{ }^{\circ} \mathrm{C}$ for $10 \mathrm{~min}$, then ultrasonically cleaned in acetone and ultrapure water. The porous titanium substrate was etched in boiling $\mathrm{HF} / \mathrm{H}_{2} \mathrm{O}_{2}$ solution (volume ratio $=5: 1$ ) at room temperature for $3 \mathrm{~min}$ to remove oxide layer and then ultrasonically cleaned in $\mathrm{H}_{2} \mathrm{O} / 37 \% \mathrm{HCl} / 30 \% \mathrm{H}_{2} \mathrm{O}_{2}$ solution (volume ratio=6:1:1) at room temperature for $10 \mathrm{~min}$ to clean additional ions.

The $\mathrm{TiO}_{2}$ nanotubes array (NTA) was formed by first anodization at a constant voltage of 30 $\mathrm{V}$ in an ethylene glycol (EG) solution containing $0.25 \mathrm{wt} \% \mathrm{NH}_{4} \mathrm{~F}$ and $2 \mathrm{wt} \% \mathrm{H}_{2} \mathrm{O}$ for $6 \mathrm{~h}$. Then, the $\mathrm{TiO}_{2}-\mathrm{NTA}$ was second anodization in the EG solution containing $5 \mathrm{wt} . \% \mathrm{H}_{3} \mathrm{PO}_{4}$ at a constant voltage of $30 \mathrm{~V}$ for $1 \mathrm{~h}$. Next, the above NTA was cathodized in $1 \mathrm{M} \mathrm{NaClO}_{4}$ solution at current density of $5 \mathrm{~mA} \cdot \mathrm{cm}^{-2}$ for $15 \mathrm{~min}$. After the twice anodization and once cathodization, the sample was ultrasonically cleaned with ultrapure water for $10 \mathrm{~min}$ to remove the sediment. Finally, the amorphous $\mathrm{TiO}_{2}-\mathrm{NTA}$ was crystallized by calcining in oxygen atmosphere for $1 \mathrm{~h}$ at $500{ }^{\circ} \mathrm{C}$ at heating rates of $1{ }^{\circ} \mathrm{C} \cdot \mathrm{min}^{-1}$ to obtain the enhanced $\mathrm{TiO}_{2}$ nanotubes array $\left(\mathrm{TiO}_{2}-\mathrm{ENTA}\right)$ intermediate layer. ${ }^{1-3}$

The $\mathrm{TiO}_{2}-$ ENTA intermediate layer was coated with mixed metal oxide catalyst layer using a sol-gel method. The tin-antimony sol-gel solution was prepared using the following steps: (1) citric acid was dissolved in EG solution with stirring at $60{ }^{\circ} \mathrm{C}$ for $30 \mathrm{~min}$ to form citrate esters. (2) the temperature of the above solution was risen to $90{ }^{\circ} \mathrm{C}$, and then $\mathrm{SnCl}_{4} \cdot 5 \mathrm{H}_{2} \mathrm{O}$ and $\mathrm{SbCl}_{3}$ were added to form the mixture solution (the mole ratio of EG: citric acid: $\mathrm{SnCl}_{4} \cdot 5 \mathrm{H}_{2} \mathrm{O}$ : $\mathrm{SbCl}_{3}=140$ : 30: 9: 1). (3) the mixture solution was kept at boiling point for $10 \mathrm{~min}$ and then allowed it to cool down to room temperature. The sol-gel solution was aged for 3 months before the dip-coating procedure. Then, the porous $\mathrm{TiO}_{2}-$ ENTA was dipped in tin-antimony sol-gel with pulling up at a speed of $5 \mathrm{~cm} \cdot \mathrm{min}^{-1}$, dried at $140{ }^{\circ} \mathrm{C}$ for $10 \mathrm{~min}$, and then calcined at $500{ }^{\circ} \mathrm{C}$ for $10 \mathrm{~min}$. This process was repeated 15 times before the anode was last annealed for $2 \mathrm{~h}$ at $500{ }^{\circ} \mathrm{C}$ and cooled down to room temperature. Finally, the porous Ti-ENTA/ $\mathrm{SnO}_{2}-\mathrm{Sb}$ electrode was obtained (Figure S2). 


\section{Text S3. Analytical Methods}

The morphology and composition of the electrodes were analyzed by field emission scanning electron microscope with an energy dispersive spectrometer (FESEM, Zeiss Ultra 60 microscope). The crystal structure of coatings was investigated using X-ray diffraction (XRD, Rigaku D$\max / 3 \mathrm{C}$ ) with $\mathrm{Cu} \mathrm{K} \alpha$ radiation $(45 \mathrm{kV}, 30 \mathrm{~mA})$. Electrochemical measurements were performed using the three-electrode cell and a CHI 660E electrochemical workstation. The porous TiENTA/ $\mathrm{SnO}_{2}-\mathrm{Sb}$ electrode was employed as working electrodes, with platinum sheet as auxiliary electrode and saturated calomel electrode (SCE) as reference electrode. Linear sweep voltammetry (LSV) was conducted at room temperature $\left(25 \pm 1^{\circ} \mathrm{C}\right)$ at a scan rate of $50 \mathrm{mV} \cdot \mathrm{s}^{-1}$ in $0.5 \mathrm{M} \mathrm{H}_{2} \mathrm{SO}_{4}$ solutions. The heavy metal ion concentrations ( $\mathrm{Sn}$ and $\mathrm{Sb}$ ) leaching during electrochemical process and metal ion concentrations in reclaimed wastewater were measured using an inductively coupled plasma optical emission spectrometry (ICP-OES, 5110, Agilent). The anion concentrations in reclaimed wastewater were measured by ion chromatography (IC1100, Thermo Scientific). The concentration of free chlorine was detected by the N,N-diethyl-pphenylenediamine (DPD) colorimetric method with a UV spectrophotometer (DR2800, Hach). The dissolved oxygen, conductivity, salinity and TDS were measured by portable water quality parameter tester.

The COD removal efficiency $\left(\eta_{C O D}\right)$ was calculated as follows 4 :

$$
\eta_{C O D}=\frac{C_{0}-C_{t}}{C_{0}} \times 100 \%
$$

where $C_{0}$ is the initial COD concentration $\left(\mathrm{mg} \cdot \mathrm{L}^{-1}\right), C_{t}$ is the COD concentration at time $t$ $\left(\mathrm{mg} \cdot \mathrm{L}^{-1}\right)$, and $t$ represents the electrolysis time $(\mathrm{min})$.

The TOC removal efficiency $\left(\eta_{\text {TOC }}\right)$ was calculated as follows:

$$
\eta_{T O C}=\frac{C_{0}-C_{t}}{C_{0}} \times 100 \%
$$

where $C_{0}$ is the initial TOC concentration $\left(\mathrm{mg} \cdot \mathrm{L}^{-1}\right), C_{t}$ is the TOC concentration at time $t$ $\left(\mathrm{mg} \cdot \mathrm{L}^{-1}\right)$.

The electrochemical oxidation of reclaimed wastewater would follow pseudo first-order reaction kinetics and the rate constant $(k)$ were calculated using equation: 


$$
\ln \left(\frac{C_{t}}{C_{0}}\right)=-k t
$$

The pressure drop curve was fitted according to the Ergun equation ${ }^{5}$ :

$$
\begin{gathered}
\frac{\Delta P}{L}=150 \times \frac{(1-\varepsilon)^{2}}{\varepsilon^{3} d^{2}} \mu \nu+1.75 \times \frac{(1-\varepsilon)}{\varepsilon^{3} d} \rho v^{2} \\
d=4 R=\frac{4 A}{C}
\end{gathered}
$$

where $\Delta P$ is the pressure drop $(\mathrm{kPa}), R$ is the hydraulic diameters $(\mathrm{cm}), A$ is the effective sectional area of the solution $\left(\mathrm{cm}^{2}\right)$, and $C$ represents the contact length between electrode wall and solution $(\mathrm{cm}), L$ is the electrode thickness $(\mathrm{cm}), \varepsilon$ is the voidage, dimensionless, $d$ is the equivalent diameter $(\mathrm{cm}), \mu$ is the viscosity of water $(\mathrm{kPa} \cdot \mathrm{s}), v$ is the flow velocity, $\mathrm{cm} \cdot \mathrm{s}^{-1}, \rho$ is the density of water $\left(\mathrm{g} \cdot \mathrm{cm}^{-3}\right)$.

The inactivation efficiency was calculated as follows ${ }^{4}$ :

$$
\log \text { inactivation efficiency }=-\log _{10}\left(\frac{N_{t}}{N_{0}}\right)
$$

where $N_{0}$ is the initial bacterial concentration $\left(\mathrm{CFU} \cdot \mathrm{mL}^{-1}\right), N_{t}$ is the bacterial concentration at time $t\left(\mathrm{CFU} \cdot \mathrm{mL}^{-1}\right)$. 


\section{Text S4. The Variation of Reclaimed Wastewater Quality Parameters}

As shown in Table S5, the conductivity value of reclaimed wastewater slightly decreased with electrolytic time in three-stage EFTM because cations in the reclaimed wastewater were adsorbed on the surface of electrodes. As the electrolysis time increased, a large amount of $\mathrm{Ca}^{2+}$ and $\mathrm{Mg}^{2+}$ in reclaimed wastewater was easily precipitated from the solution to form low soluble precipitates on the cathode surface, resulting in the decline of salinity and TDS values of reclaimed wastewater. The reaction processes as following6:

$$
\begin{gathered}
\mathrm{Ca}^{2+}+\mathrm{CO}_{3}^{-} \rightarrow \mathrm{CaCO}_{3} \downarrow \\
\mathrm{Mg}^{2+}+2 \mathrm{OH}^{-} \rightarrow \mathrm{Mg}(\mathrm{OH})_{2} \downarrow \\
\mathrm{Ca}^{2+}+\mathrm{Mg}^{2+}+2 \mathrm{OH}^{-}+\mathrm{HCO}_{3}^{-} \rightarrow \mathrm{CaMg}^{2}\left(\mathrm{CO}_{3}\right)_{2} \downarrow+2 \mathrm{H}_{2} \mathrm{O}
\end{gathered}
$$




\section{Text S5. The Calculation of Electrode Numbers for the Practical Flow Velocity}

It could be obtained from Figure S10 that the rate constants of the practical flow velocity (Table S7). The required time was calculated using equation (2) when the COD removal efficiency and bacterial inactivation reached to $90 \%$ and $8 \mathrm{logs}$, respectively. Therefore, the electrode numbers of the practical flow velocity were calculated by the following:

$$
\mathrm{n}=\frac{S \times v \times t}{V^{\prime}}
$$

where $\mathrm{n}$ is the numbers of electrode with the thickness of $3 \mathrm{~mm}, \mathrm{~S}$ is electrode area $\left(\mathrm{cm}^{2}\right), v$ is the practical flow velocity $\left(\mathrm{cm} \cdot \mathrm{s}^{-1}\right), t$ represents the electrolysis time (s) and $V^{\prime}$ is the required solution volume for the regenerated wastewater with a flow velocity of $0.2 \mathrm{~cm} \cdot \mathrm{s}^{-1}$ to completely pass a pair of electrodes in $40 \mathrm{~s}$ according to the simulation experiment $(\mathrm{mL})$. 

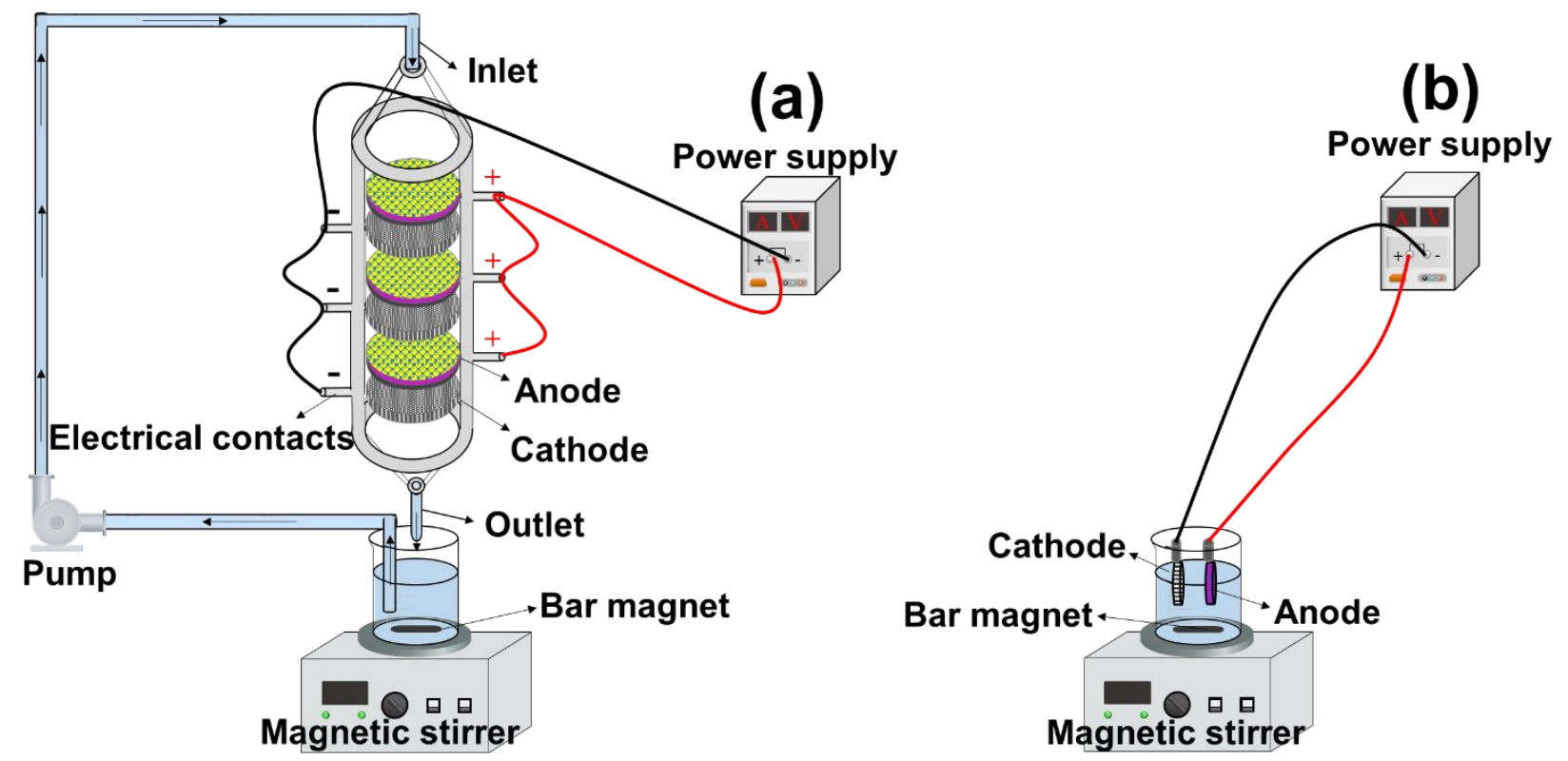

Figure S1. The illustrative diagram of (a) Three-stage electrochemical flow-through mode and (b) Flow-by mode 


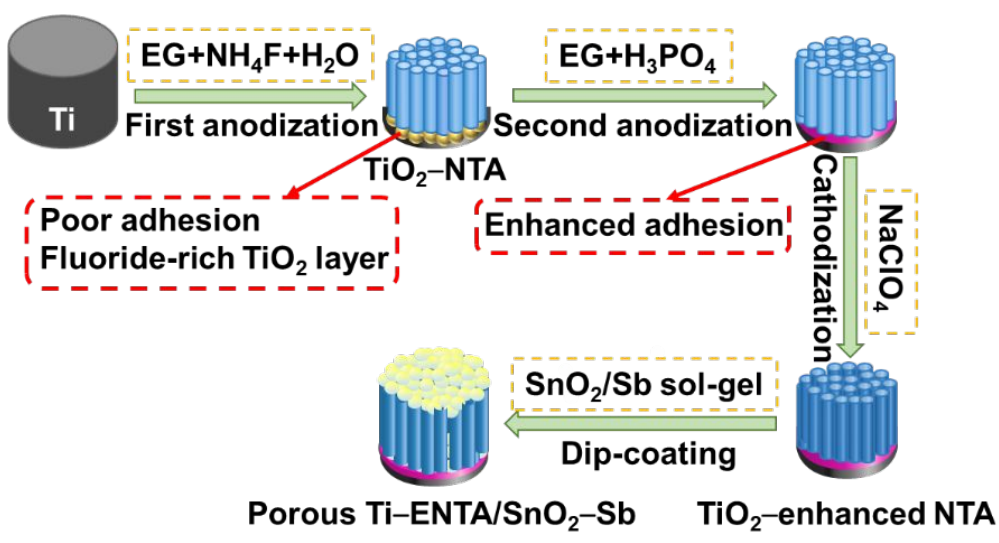

Figure S2. The schematic diagram of novel anode preparation process 

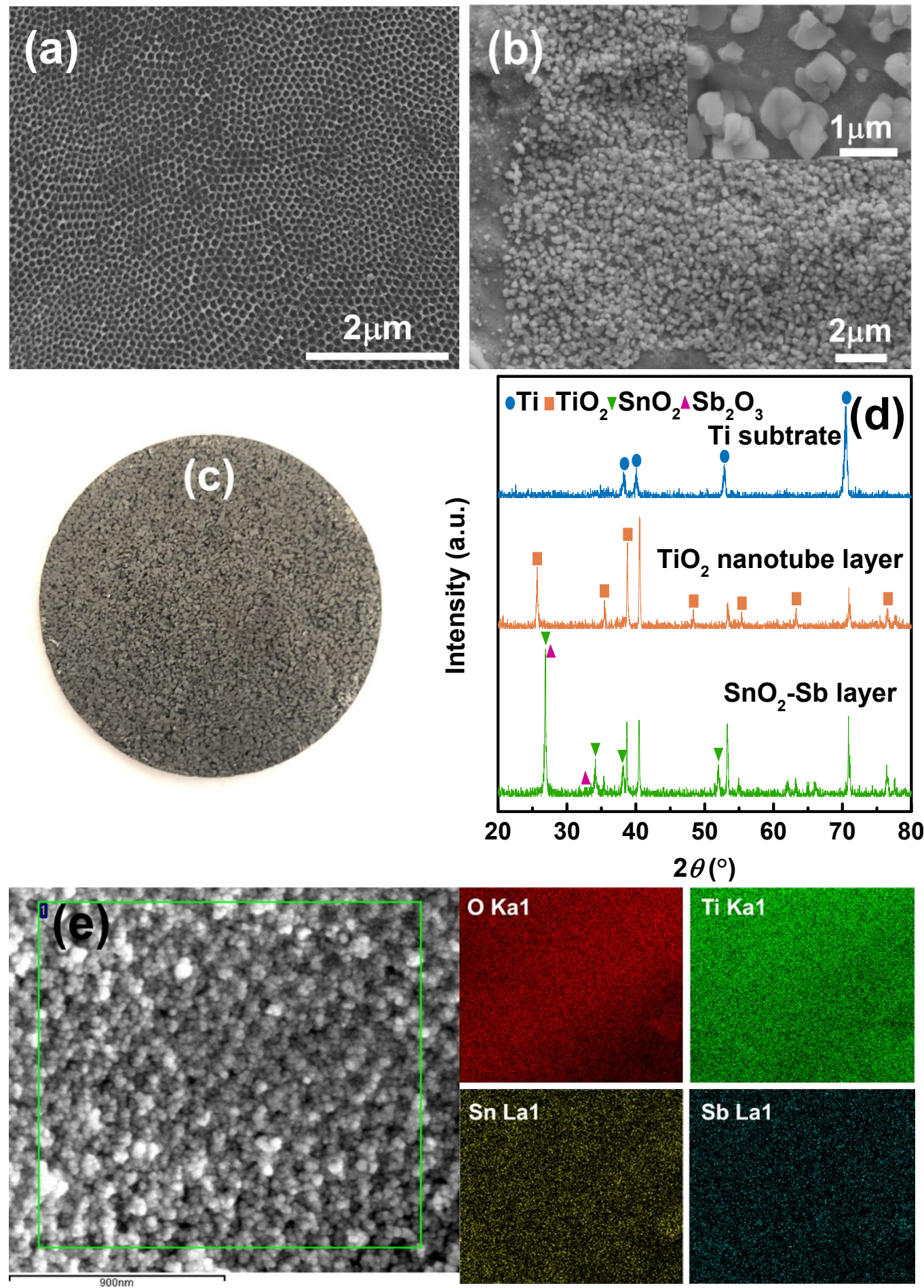

Figure S3. The SEM images of (a) $\mathrm{TiO}_{2}$ nanotube layer and (b) porous $\mathrm{Ti}-\mathrm{ENTA} / \mathrm{SnO}_{2}-\mathrm{Sb}$ electrode (nominal pore size: $50 \mu \mathrm{m}$ ); The (c) SEM picture, (d) XRD spectra and (e) EDS of porous $\mathrm{Ti}-\mathrm{ENTA} / \mathrm{SnO}_{2}-\mathrm{Sb}$ electrode 

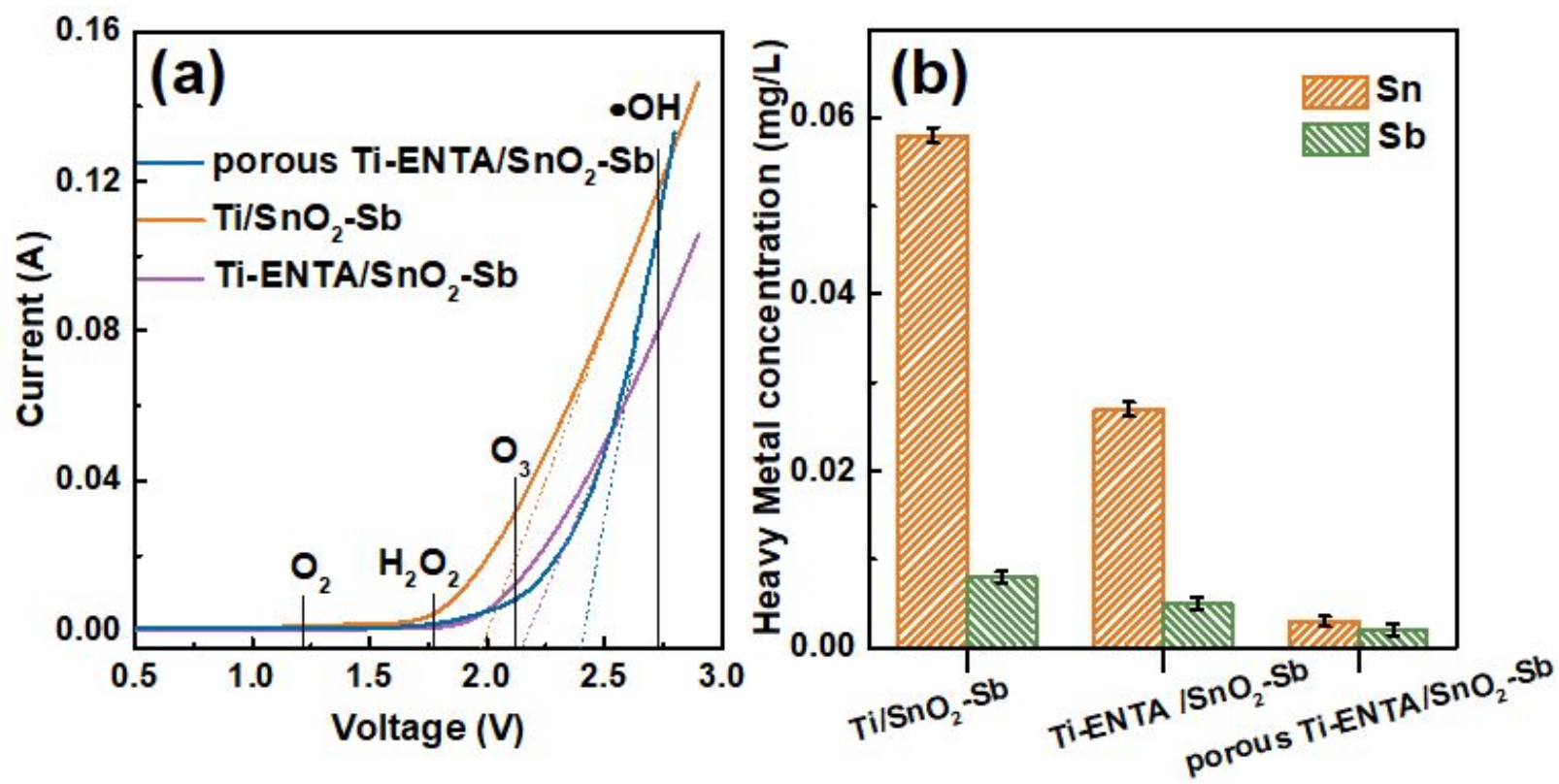

Figure S4. (a) LSV curves of different electrodes; (b) The comparison of heavy metal leaching concentration for different electrodes 


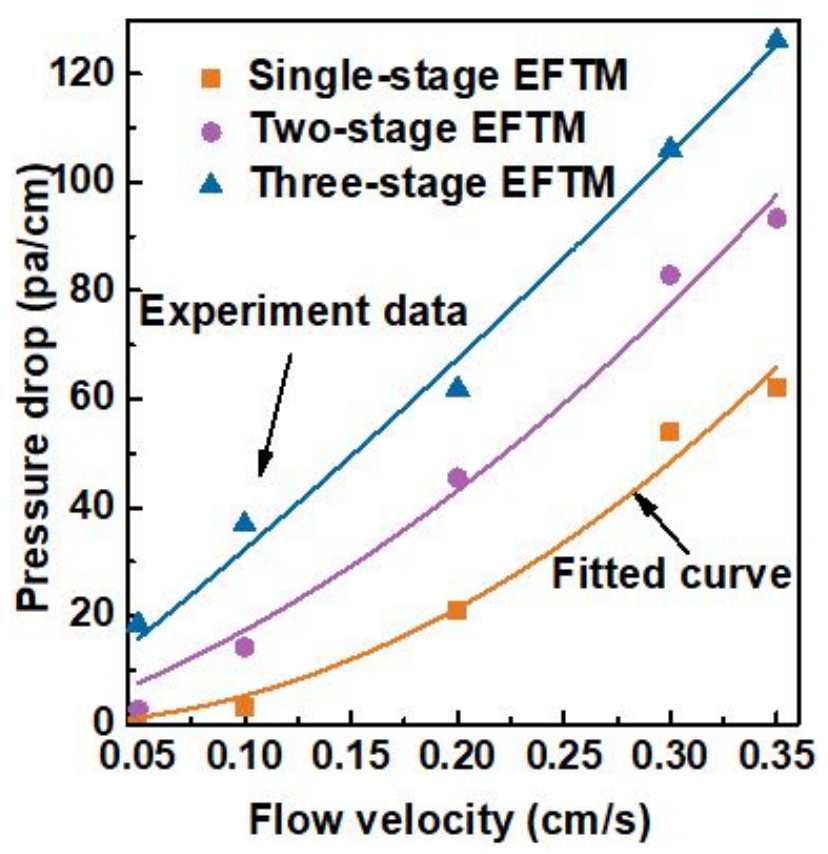

Figure S5. Variation of pressure drop for different modes with the flow velocity 


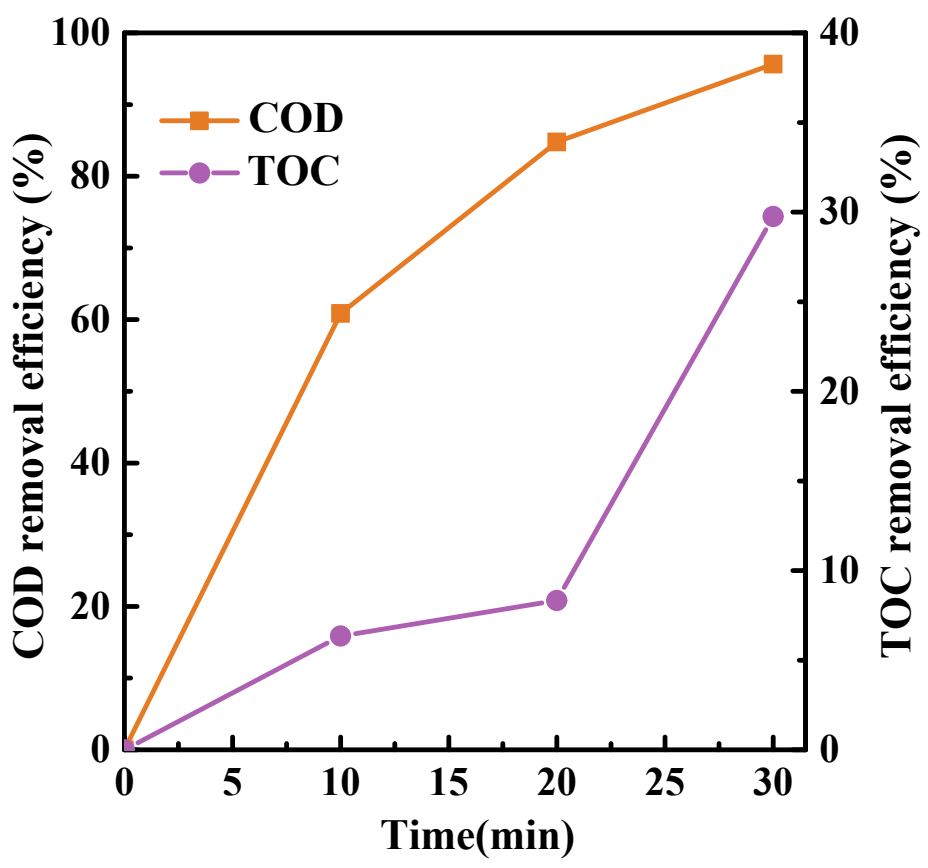

Figure S6. Comparison of the COD and TOC removal efficiency by using the three-stage EFTM 


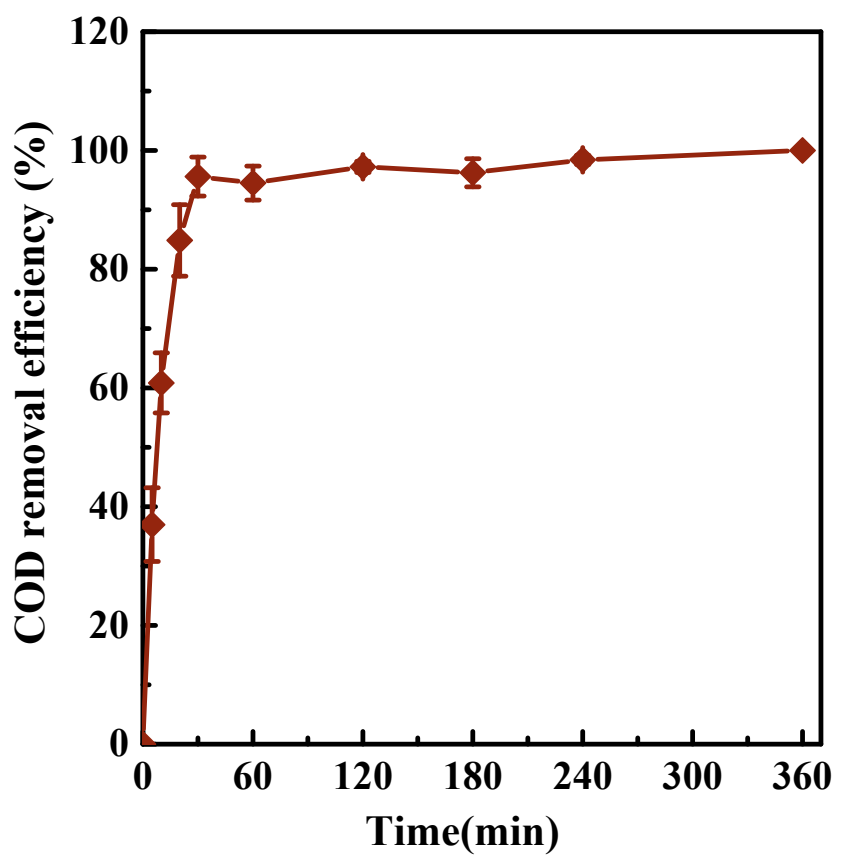

Figure S7. The long-term performance of the three-stage EFTM during treatment process 

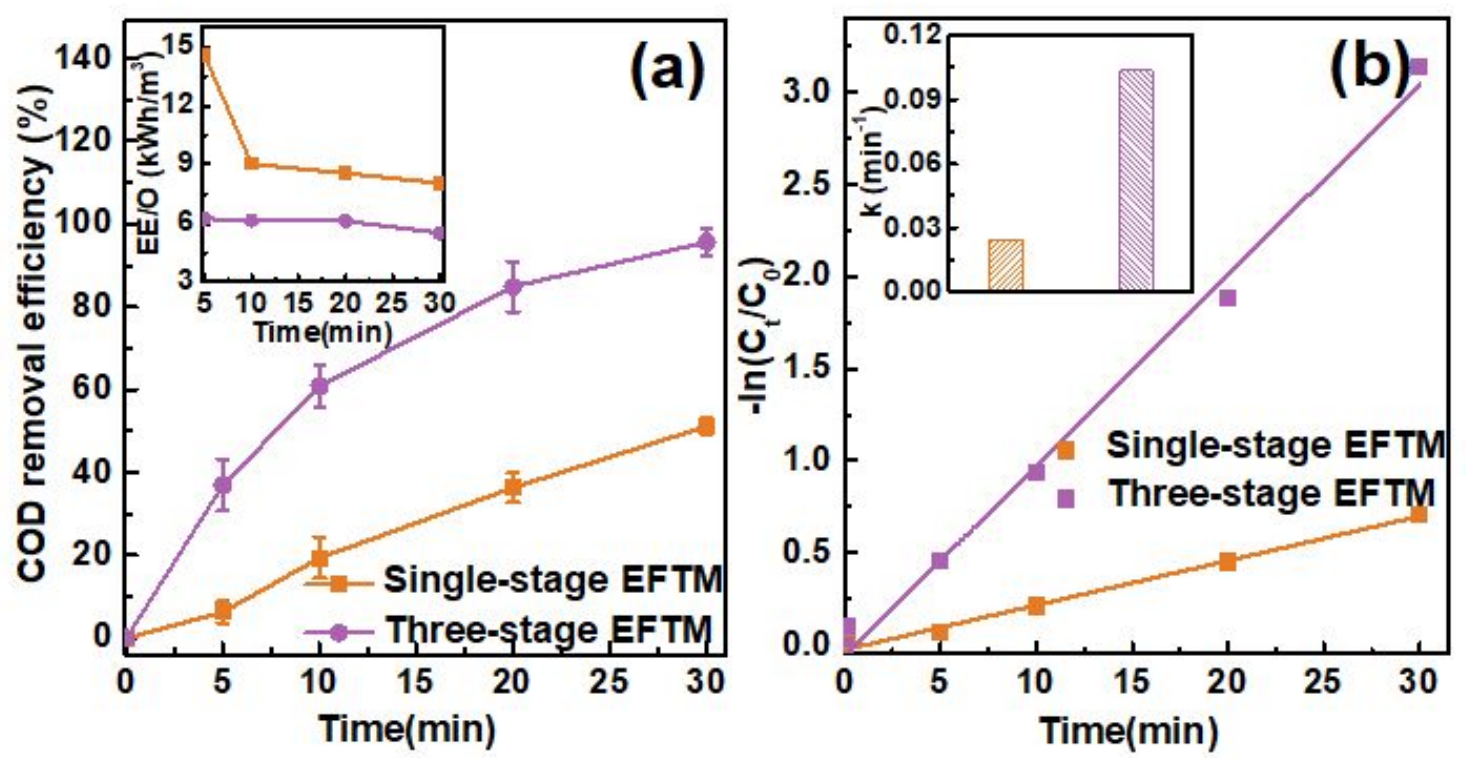

Figure S8. Effect of different stage numbers on (a) COD removal efficiency and (b) pseudo firstorder kinetic fitting by single-stage EFTM and three-stage EFTM. The inserted plots in (a) and (b) are the EE/O and pseudo first-order rate constants at different current density, respectively 

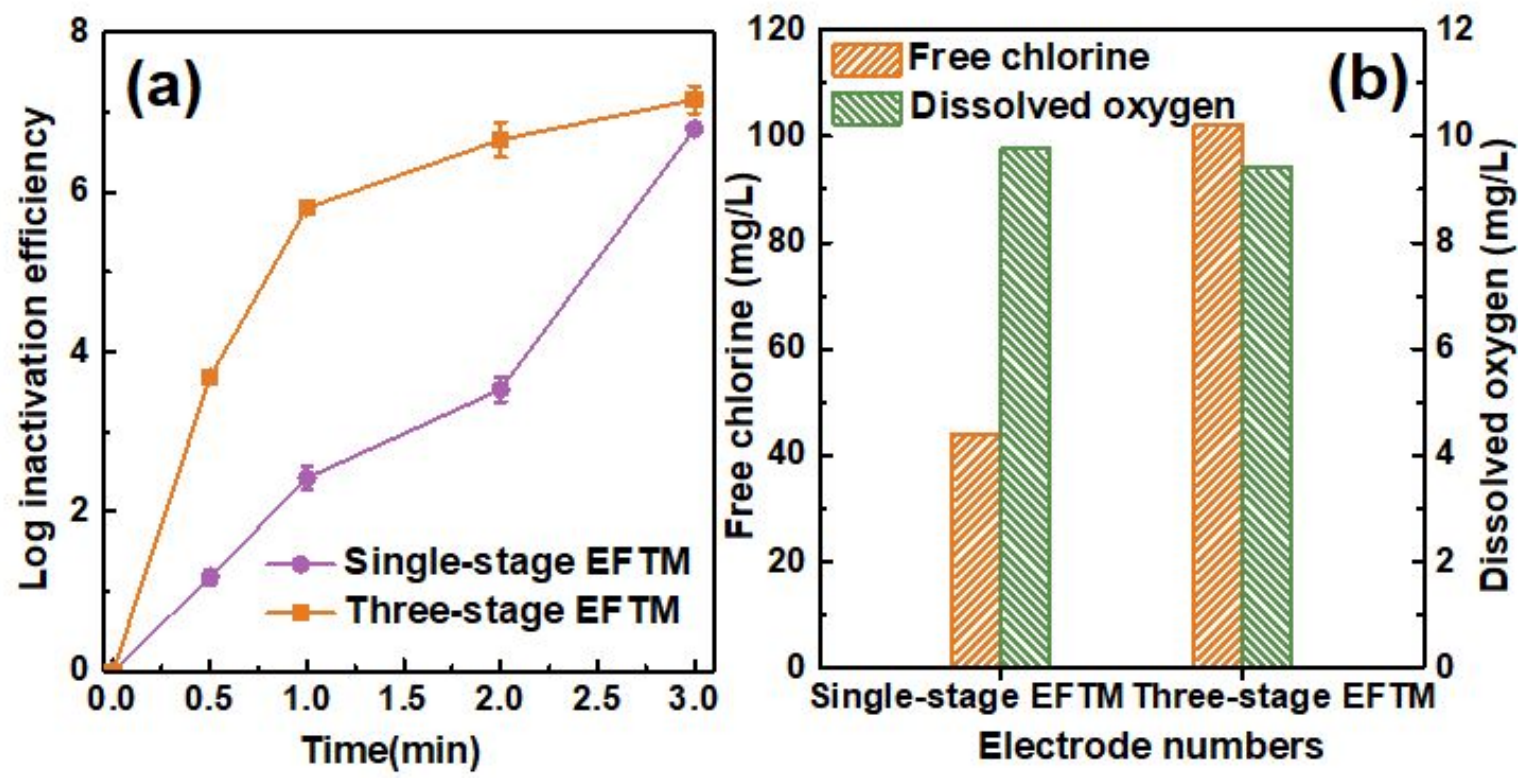

Figure S9. Effect of stage numbers on (a) bacterial inactivation and (b) the concentration of free chlorine and dissolved oxygen by using the three-stage EFTM 


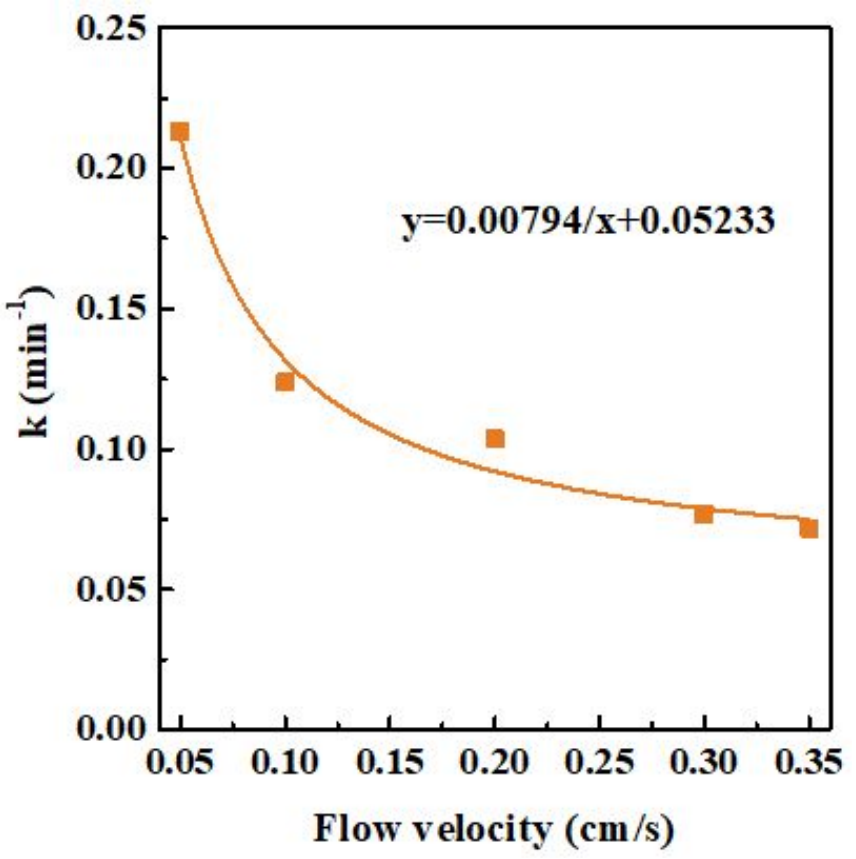

Figure S10. Effects of flow velocity on pseudo first-order kinetic fitting by rate constants (k) 
Table S1. The water quality of the reclaimed wastewater sample

\begin{tabular}{cccccc}
\hline Parameters & unit & value & Parameters & unit & value \\
\hline $\mathrm{pH}$ & 1 & $7.68-8.34$ & $\mathrm{Mg}^{2+}$ & $\mathrm{mg} \cdot \mathrm{L}^{-1}$ & 126.3 \\
$\mathrm{BOD}_{5}$ & $\mathrm{mg} \cdot \mathrm{L}^{-1}$ & $0.08-0.09$ & $\mathrm{~K}^{+}$ & $\mathrm{mg} \cdot \mathrm{L}^{-1}$ & 130.9 \\
$\mathrm{COD}$ & $\mathrm{mg} \cdot \mathrm{L}^{-1}$ & $40-60$ & $\mathrm{Na}^{+}$ & $\mathrm{mg} \cdot \mathrm{L}^{-1}$ & 872.25 \\
$\mathrm{TDS}$ & $\mathrm{mg} \cdot \mathrm{L}^{-1}$ & 2230 & $\mathrm{SO}_{4}{ }^{2-}$ & $\mathrm{mg} \cdot \mathrm{L}^{-1}$ & 421.86 \\
$\mathrm{DO}$ & $\mathrm{mg} \cdot \mathrm{L}^{-1}$ & 7.35 & $\mathrm{NO}_{2}^{-}$ & $\mathrm{mg} \cdot \mathrm{L}^{-1}$ & 1458.11 \\
$\mathrm{Ca}{ }^{2+}$ & $\mathrm{mg} \cdot \mathrm{L}^{-1}$ & 607.75 & $\mathrm{Br}^{-}$ & $\mathrm{mg} \cdot \mathrm{L}^{-1}$ & 542.46 \\
Salinity & $\%$ & 0.27 & $\mathrm{~F}^{-}$ & $\mathrm{mg} \cdot \mathrm{L}^{-1}$ & 0.24 \\
Conductivity & $\mu \mathrm{S} \cdot \mathrm{cm}^{-1}$ & 4370 & $\mathrm{PO}_{4}{ }^{3-}$ & $\mathrm{mg} \cdot \mathrm{L}^{-1}$ & 2.60 \\
\hline
\end{tabular}


Table S2. The pressure drop curve for different modes

\begin{tabular}{ccc}
\hline Modes & Fitting formulas & $\mathrm{R}^{2}$ \\
\hline Single-stage EFTM & $\mathrm{y}=80.813 \mathrm{x}^{2}-0.135 \mathrm{x}$ & 0.98 \\
Two-stage EFTM & $\mathrm{y}=38.925 \mathrm{x}^{2}+11.239 \mathrm{x}$ & 0.98 \\
Three-stage EFTM & $\mathrm{y}=11.651 \mathrm{x}^{2}+25.958 \mathrm{x}$ & 0.98 \\
\hline
\end{tabular}


Table S3. The element content percentage of porous Ti-ENTA/SnO ${ }_{2}-\mathrm{Sb}$ electrode

\begin{tabular}{cccc}
\hline Elements & Element concentration & Weight percentage (\%) & Atoms percentage (\%) \\
\hline $\mathrm{Ti}$ & 49.40 & 33.80 & 61.57 \\
$\mathrm{O}$ & 8.06 & 61.12 & 37.18 \\
$\mathrm{Sn}$ & 3.90 & 4.65 & 1.14 \\
$\mathrm{Sb}$ & 0.36 & 0.43 & 0.10 \\
\hline
\end{tabular}


Table S4. The comparison of heavy metal leaching concentration

\begin{tabular}{ccc}
\hline Electrodes & $\mathrm{Sn}$ & $\mathrm{Sb}$ \\
\hline $\mathrm{Ti} / \mathrm{SnO}_{2}-\mathrm{Sb}$ & $0.058 \mathrm{mg} \cdot \mathrm{L}^{-1}$ & $0.009 \mathrm{mg} \cdot \mathrm{L}^{-1}$ \\
$\mathrm{Ti}-\mathrm{ENTA} / \mathrm{SnO}_{2}-\mathrm{Sb}$ & $0.027 \mathrm{mg} \cdot \mathrm{L}^{-1}$ & $0.006 \mathrm{mg} \cdot \mathrm{L}^{-1}$ \\
Porous Ti-ENTA $/ \mathrm{SnO}_{2}-\mathrm{Sb}$ & $0.005 \mathrm{mg} \cdot \mathrm{L}^{-1}$ & $0.004 \mathrm{mg} \cdot \mathrm{L}^{-1}$ \\
\hline
\end{tabular}


Table S5. The variation of water quality parameters for three-stage EFTM

\begin{tabular}{cccccc}
\hline $\begin{array}{c}\text { Time } \\
(\mathrm{min})\end{array}$ & $\begin{array}{c}\text { Residual chlorine } \\
\left(\mathrm{mg} \cdot \mathrm{L}^{-1}\right)\end{array}$ & $\begin{array}{c}\text { Do } \\
\left(\mathrm{mg} \cdot \mathrm{L}^{-1}\right)\end{array}$ & $\begin{array}{c}\text { Salinity } \\
(\%)\end{array}$ & $\begin{array}{c}\text { TDS } \\
\left(\mathrm{mg} \cdot \mathrm{L}^{-1}\right)\end{array}$ & $\begin{array}{c}\text { Conductivity } \\
\left(\mu \mathrm{S} \cdot \mathrm{cm}^{-1}\right)\end{array}$ \\
\hline 0 & 0 & 7.35 & 0.27 & 2230 & 4370 \\
5 & 42 & 9.64 & 0.25 & 2020 & 4250 \\
10 & 57 & 9.55 & 0.24 & 1976 & 3950 \\
20 & 78 & 9.46 & 0.23 & 1932 & 3860 \\
30 & 110 & 9.42 & 0.23 & 1896 & 3790 \\
\hline
\end{tabular}


Table S6. The property comparison of different types of technology in the oxidation of reclaimed wastewater

\begin{tabular}{cccc}
\hline Technology type & $\begin{array}{c}\text { Reaction time } \\
(\mathrm{min})\end{array}$ & $\begin{array}{c}\text { COD initial } \\
\text { concentration }\left(\mathrm{mg} \cdot \mathrm{L}^{-1}\right)\end{array}$ & $\begin{array}{c}\text { COD removal } \\
\text { efficiency (\%) }\end{array}$ \\
\hline Electrochemical oxidation $^{7}$ & 120 & $120-190$ & 83.34 \\
This work & 30 & $50 \pm 10$ & 95.65 \\
Fenton $^{8}$ & 30 & $70 \pm 10$ & 67 \\
Ultrafiltration $^{9}$ & 70 & $1500-2500$ & 66 \\
\hline
\end{tabular}


Table S7. Parameters that used for practical flow velocity simulation

\begin{tabular}{ccccc}
\hline Flow velocity $\left(\mathrm{m} \cdot \mathrm{s}^{-1}\right)$ & $k\left(\mathrm{~min}^{-1}\right)$ & $t(\mathrm{~min})$ & Pipe length $(\mathrm{m})$ & Electrode numbers \\
\hline 0.5 & 0.0524 & 45 & 1178 & 236 \\
0.6 & 0.0524 & 45 & 1413 & 283 \\
0.7 & 0.0524 & 45 & 1649 & 330 \\
0.8 & 0.0524 & 45 & 1884 & 377 \\
\hline
\end{tabular}

${ }^{a}$ The electrodes numbers were calculated by the thickness of $10 \mathrm{~cm}$. 


\section{References}

(1) Yang, Y.; Hoffmann, M. R. Synthesis and Stabilization of Blue-Black $\mathrm{TiO}_{2}$ Nanotube Arrays for Electrochemical Oxidant Generation and Wastewater Treatment. Environ. Sci. Technol. 2016, 50, 1188811894, DOI: 10.1021/acs.est.6b03540.

(2) Meng, X. Y.; Chen, Z. F.; Wang, C.; Zhang, W. Q.; Zhang, K. H.; Zhou, S. Q.; Luo, J. M.; Liu, N.; Zhou, D. D.; Li, D.; Crittenden, J. Development of a Three-Dimensional Electrochemical System Using a Blue $\mathrm{TiO}_{2} / \mathrm{SnO}_{2}-\mathrm{Sb}_{2} \mathrm{O}_{3}$ Anode for Treating Low-Ionic-Strength Wastewater. Environ. Sci. Technol. 2019, 53(23), 13784-13793, DOI: 10.1021/acs.est.9b05488.

(3) Li, P. Q.; Zhao, G. H.; Cui, X.; Zhang, Y. G.; Tang, Y. T. Constructing Stake Structured $\mathrm{TiO}_{2}-\mathrm{NTs} / \mathrm{Sb}$ Doped $\mathrm{SnO}_{2}$ Electrode Simultaneously with High Electrocatalytic and Photocatalytic Performance for Complete Mineralization of Refractory Aromatic Acid. J. Phys. Chem. C. 2009, 113, 2375-2383, DOI: 10.1021/jp8078106.

(4) Duan, Y.; Chen, Y.; Wen, Q.; Duan, T. G. Fabrication of dense spherical and rhombic Ti/Sb-SnO 2 electrodes with enhanced electrochemical activity by colloidal electrodeposition. J. Electroanal. Chem. 2016, 768, 81-88, DOI: 10.1016/j.jelechem.2016.02.044.

(5) Zhang, X. M.; Ling, Y.; Wang, J. P.; Gu, Q. Y. Study of the flow resistance characteristics in graphite foam based on Ergun equation. Carbon. Tech. 2011, 30(5), 17-20, DOI: 10.14078/j.cnki.10013741.2011.05.015.

(6) Li, X. Y.; Wang, C. W.; Qian, Y.; Wang, Y. J.; Zhang, L. W. Simultaneous removal of chemical oxygen demand, turbidity and hardness from biologically treated citric acid wastewater by electrochemical oxidation for reuse. Sep. Purif. Technol. 2013, 107, 281-288, DOI: 10.1016/j.seppur.2013.01.008.

(7) Zhou, M. H.; Liu, L.; Jiao, Y. L.; Wang, Q.; Tan, Q. Q. Treatment of high-salinity reverse osmosis concentrate by electrochemical oxidation on BDD and DSA electrodes. Desalination. 2011, 277, 201-206, DOI: 10.1016/j.desal.2011.04.030.

(8) Wang, Y. C.; Wang, C.; Shi, S.; Fang, S. Improved removal performance and mechanism investigation of papermaking wastewater treatment using manganese enhanced Fenton reaction. Water Sci. Technol. 2018, DOI: $10.2166 /$ wst.2018.208.

(9) Barredo-Damas, S.; Alcaina-Miranda, M.I.; Iborra-Clar, M.I. Bes-Piá, A.; Mendoza-Roca, J. A.; IborraClar, A. Study of the UF process as pretreatment of NF membranes for textile wastewater reuse. Desalination. 2006, 200, 745-747, DOI: 10.1016/j.desal.2006.03.497. 